\title{
The Analysis of Cultivation and Improvement of Language Writing Ability in Art Design Education in Colleges and Universities
}

\author{
Ming Yang \\ Huaiyin Normal University, Huai'an Jiangsu, 223001, China
}

Keywords: Higher education, Art design, Language writing ability, Talent cultivation.

\begin{abstract}
Culture is a valuable asset formed by the Chinese nation in the course of its long development. In the cultivation of talents and educational practice in colleges and universities, it is necessary to correctly understand the importance of cultural inheritance and communication, and through the improvement of students 'language skills to promote students' cultural heritage and dissemination. Based on this, the practice of art design education in colleges and universities should focus on the cultivation of students 'application ability in words and phrases, hoping to improve the students' application ability in words and phrases step by step, to promote the comprehensive artistic design ability of students, and to provide students' future development with the corresponding guarantee.
\end{abstract}

\section{Introduction}

Cultivating students' language ability in educational practice can effectively promote the strengthening of college students' professional ability and the cultivation of comprehensive quality, which has a crucial influence on students' personal growth and comprehensive development in the future. In the process of personnel training in colleges and universities, the teaching of art should realize the importance of cultivating students 'language ability, and actively explore the corresponding language ability training measures, hoping to gradually improve the students' language ability and promote the strengthening of the core competitiveness of students, who will become a high-quality talent for the development of art and design industry to contribute to a certain strength.

\section{The Current Situation of Cultivation of Language Writing Ability of Art Design Students in Colleges and Universities}

By studying and analyzing the current situation of language ability of art students in colleges and universities, It is found that although the school has begun to realize the importance of cultivating students' language ability, and actively explores the corresponding measures. But from the whole point of view, there are still some problems, which have the corresponding adverse effects on the cultivation of students' language application ability.

The students are short of knowledge for language, the accumulation of professional theory is poor

The students of art design in colleges and universities show a certain degree of particularity in the course of learning. Some students have not yet realized the importance of literature and technology and language ability, Therefore, the cultivation of comprehensive quality is relatively neglected. The lack of knowledge of language has a certain degree of restrictive effects on the cultivation of students' professional ability. There are some students in the theoretical level to recognize the importance of language ability. But in the actual learning process, the Learning motivation is low and the autonomy is not enough, which can have an negative effect on the cultivation of students' language application 
ability. Students can not learn and explore the professional knowledge of language and professional language in art design, and finally the students' ability to cultivate language skills is relatively poor.

\section{The difficulty of constructing the knowledge language system for students}

At present, China's art education has shown great emphasis on practical teaching activities, and influenced by this kind of educational thought. Some students think that the formation of artistic accomplishment is closely related to practice teaching. Therefore, the study of theoretical knowledge is relatively neglected. The process does not pay attention to their own language skills to be trained, resulting in the overall learning effect of students is relatively poor. In other words, under the condition that the students neglect the theory teaching, the traditional clue knowledge structure formed by the students in the learning process will be destroyed gradually. The construction of the language knowledge system is hindered, which leads to the unsatisfactory student's overall learning effect , The students' personal development have a certain restrictive impact.

\section{The deviation from the application of language in daily life}

In the study and life, students can be proficient in the use of language knowledge which is the necessary professional skills that college students should master, especially for art students. The formation of students 'artistic accomplishment and the cultivation of students' language ability have some connection[1]. However, in the current practice of art design teaching in Chinese colleges and universities, the cultivation of students' language ability is neglected, and there are some deviations in the application of everyday language. Teachers and students do not form the consciousness and ability to use the text according to the norms of language. Resulting in students in the process of education and teaching activities in the language skills are not well trained, which has a certain restrictive impact on the development of students and the future development of professional work to produce.

\section{The measure of strengthening the Students' Language and Writing Ability in Art Design Teaching in Colleges and Universities}

In view of the current situation of the cultivation of students' language ability in the teaching of arts and design in colleges and universities at present, teachers in language and professional should know the importance of current educational reform and actively explore the reform and innovation of art design specialty. Hoping to gradually improve the language teaching professional status quo, to promote the overall quality of students to cultivate, and strive to cultivate students with high professional ability of talents for the development of China's art and design areas to provide appropriate support and protection. In particular, the cultivation of students' language ability in college art design teaching can be systematically studied from the following aspects.

\section{Attach great importance to language education, the traditional teaching model reform and innovation}

Art design students in the process of writing the design of the works want to accurately convey the spirit of the work of the work, which needs a deep cultural heritage and language literacy support. Therefore, we should strengthen the emphasis on Chinese teaching in the teaching of art design in colleges and universities, and promote the cultivation of students' language ability through language teaching. In this teaching practice, it should be noted that teachers attach importance to the humanistic spirit of Chinese teaching, but also to strengthen their instrumental concerns. Hoping to use its instrumental support to promote the enhancement of students' language ability, to create good conditions for the cultivation of comprehensive quality of language and the strengthening of design comprehensive ability for the art design students[2]. In this process, teachers should pay attention to the reform and innovation of traditional language teaching activities, strengthen the emphasis on language practice activities, combine the needs of art design students to adjust the teaching activities appropriately, combine with art design students 'characteristics of outstanding personality and thinking active. In the classroom, creating a good teaching atmosphere can effectively stimulate 
students' interest in learning, so that students will actively participate in classroom discussion practice. In the speech, questioning and discussion, students will train their language skills and conduct intensive training to their skills in the subtle influence, which can ensure the learning effects of students and provide students with appropriate support and assistance to gain more knowledge about art and design.

\section{To effectively improve the students' awareness of language norms, to create a good learning environment for students}

Strengthening the Cultivation of Students' Language and Writing Ability in Teaching Activities of Art Design can allow students to gradually recognize the importance of language skills, then in the learning process consciously follow the relevant language norms and improve their own language skills, which can promote the cultivation of the overall artistic design ability and provide students with appropriate protection for the future development. Therefore, in the art design teaching activities, teachers should guide students' behavior of language application combined with the "National General Law", which can help students really realize the importance of language. And in the campus cultural activities to strengthen the publicity and education of the norms of the language, hoping to create a good learning environment for students, so that students consciously strengthen the language application norms, with a view to promote the overall learning ability of students.

In the university teaching activities, the school not only to ensure that the effect of publicity, teachers should also be aware of their importance in guiding students, set good examples and then take the right lead in the study of students. In the layout of the campus culture environment, schools should pay attention to the normative nature of public language, such as newspaper, propaganda slogans, signs and document certificates, etc., and to cultivate language normative application ability of students in the subtle influence[3] . At the same time colleges and universities should also realize that the school website and radio stations can play a role in promoting the school culture . To improve the level of language norms and to create a good language norm environment for students, which can ensure that students under the influence of the environment can consciously regulate their own behavior, to strengthen the application of language proficiency training, and effectively ensure the learn outcome of students, to promote students to learn the whole ability to improve. Only in this way can the teaching of art design in colleges and universities be able to improve the teaching situation step by step, and the language application ability of students can also be effectively regulated, which is of vital importance to the cultivation of students' comprehensive practical ability and the future development of students.

\section{The full analysis of students' learning needs, build a scientific skills training system}

The cultivation of language ability of art and design students is closely related to the construction of the environment and the guidance of teachers. But the more important point is the skill training. Only by combining the growth demand of art and design students, can students gradually improve their language skills under the guidance of the role of the professional teaching and learn a comprehensive learning ability to get a good training, so on the basis of comprehensively analyzing the demand of art and design professional learning and the future professional development, teachers should be combined with the students of the professional theory courses to actively explore the development of the new curriculum for students to implement relatively scientific skills training guidance. In the process of developing and exploring educational courses, the teachers of art and design specialties should pay more attention to the courses such as "speech and eloquence", "Putonghua", "applied writing" and "oral expression". and implement targeted guidance for students on the language skills in these courses to promote the students a comprehensive improvement in language and language ability.

In the system to grasp the students on the basis of learning, art design professional teachers should also organize students to participate in extracurricular training links. on the one hand combined with the construction of campus culture, so that students participate in the process of building a campus culture to accept basic training to ensure that students training effect. For example teachers can organize students to participate in recitation training, speech training, so that students participate in 
the standardization of the debate activities in the promotion of Mandarin at the same time also promote the cultivation of students' language skills, and strive to cultivate students into high-quality talent. At the same time, in view of the reality of the revival of Chinese studies in recent years, art and design teachers in order to promote students' comprehensive cultural literacy training. They can also try to host the Chinese classic reading contest, idiom contest and poetry contest, in regulating the application of students 'language at the same time also promote the cultivation of students' comprehensive cultural quality, to provide the appropriate support and protection for the art of professional design students to become high-quality talents[4].

\section{To guide students to pay attention to strengthen their own language literacy ability}

In the teaching practice of art design in colleges and universities, students' personal attention to language ability has a very important impact on the strengthening of students 'learning effect and the cultivation of students' language ability. Therefore, in the teaching activities, teachers should pay attention to play their own teaching and guiding role, so that students take the initiative to participate in learning activities, consciously develop their own language skills, and promote the cultivation of students' comprehensive literacy, which can lay a solid foundation for the students to become high-quality art and design talent. First of all, teachers should guide students to study professional courses and language related courses[5]. Art design students should recognize the importance of language expression and the language of their own professional ability to develop the impact, and then in the learning process not only concerned about the study of professional knowledge, but also be able to consciously explore the training and improvement of language skills.

Students should actively participate in theoretical learning activities and enrich their own professional knowledge system to complete the construction of professional knowledge, which can promote the cultivation of students' comprehensive quality. In the process of specific creative design practice, students should consciously accept the guidance of teachers, and consciously express their own design ideas with words out, so that more people can understand and understand their own design ideas, triggering the feelings of other listeners Resonance, and then realize the value of art design works. Second, in the study and exploration activities, students should consciously accumulate the language of the material to lay a solid foundation for the gradual improvement of language ability. Art design students should clearly understand that only when they accumulate enough language material, can they obtain a good language skill, so throughout the study activities, students should be conscious, purposeful, planned to strengthen the accumulation of language and writing materials, help themselves to obtain language knowledge, promote the establishment of knowledge system, which can for create good conditions.

For their own language literacy training. In this way, in the student's attention and conscious efforts to study, explore, art design students' language ability can be cultivated. Students' artistic and design professional ability can also be improved, which can have an crucial impact on the individual development of students and the steady development of China's art and design areas.

\section{Conclusion}

In the practice of personnel training in colleges and universities, the ability of language of art design students not only has an important influence on the personal development of students, but also related to the development of art design major. Even when students have entered into the art design profession, the overall quality of students will also have an important impact on the development of the industry. Therefore, colleges and universities should correctly understand the importance of cultivating students' language ability, and actively explore the corresponding training measures, hoping to improve the cultivation of the status quo and promote the improvement of the overall quality of personnel training, which can provide the corresponding talent protection for the development of China's art and design industry. 


\section{References}

[1] Cui Lei. Study on the cultivation and improvement of language ability in art design education in colleges and universities, Abstract Edition: Education, 2015 (6): 126-126.

[2] Zhu Fangqiong. Art analysis of the application ability of language students in language students, Journal of Hubei University of Economics (Humanities and Social Sciences), 2012, 9 (7): 177-178.

[3] Wang Haifeng. College entrance examination language use question answer strategy - Jiangsu volume as an example, Shanghai Normal University, 2015.

[4] Yang Xin, Ding Shuping. Study on the Cultivation of Students' Language and Writing Ability in Higher Vocational Colleges, Time Education, 2016 (22): 4-4.

[5] Chen Chunlei. Application of college students in the application of language proficiency in the status quo, value and reform path - Chizhou University as an example, Modern language, 2017 (2): 151-154. 